Jurnal Kesmas Asclepius

Volume 1, Nomor 2, Desember 2019

e-ISSN: 2684-8287

p-ISSN: 2656-8926

DOI: https://doi.org/10.31539/jka.v1i2.577

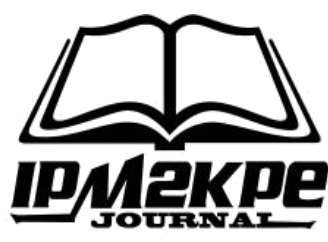

\title{
ANALISIS HUBUNGAN PEMBERIAN ASI EKSKLUSIF DAN PENDIDIKAN IBU TERHADAP PERKEMBANGAN BAYI
}

\author{
Dewi Sartika Siagian ${ }^{1}$, Sara Herlina ${ }^{2}$ \\ Universitas Abdurrab ${ }^{1,2}$ \\ dewi.sartika.siagian@univrab.ac.id ${ }^{1}$
}

\begin{abstract}
ABSTRAK
Tujuan penelitian ini adalah untuk mengetahui hubungan pemberian ASI eksklusif dan pendidikan ibu terhadap perkembangan bayi. Penelitian ini bersifat kuantitatif analitik observasional dengan desain cross sectiona. Hasil analisa univariat menunjukkan sebagian besar bayi mendapatkan ASI eksklusif sebanyak 46 orang $(55,4 \%)$, pendidikan rendah sebanyak 56 orang $(67,5 \%)$ dan sebagian besar perkembangan normal sebesar 47 orang $(56,6 \%)$. Hasil analisa bivariat pemberian ASI Eksklusif terhadap perkembangan bayi dengan uji chi square diperolah nilai $\mathrm{P}$ value $<0,000$. Simpulan, ada hubungan antara pemberian ASI Eksklusif terhadap perkembangan bayi dan analisa bivariat pendidikan ibu terhadap perkembangan bayi. Ada hubungan antara pendidikan ibu terhadap perkembangan bayi.
\end{abstract}

Kata Kunci: ASI Eksklusif, Pendidikan Ibu, Perkembangan Bayi

\section{ABSTRACT}

The purpose of this study was to determine the relationship of exclusive breastfeeding and mother's education on infant development. This research is a quantitative observational analytic with cross sectional design. The results of univariate analysis show that most babies get exclusive breastfeeding as many as 46 people (55.4\%), low education as many as 56 people (67.5\%) and most of the normal development of 47 people ( $56.6 \%)$. The results of bivariate analysis of exclusive breastfeeding for infant development by chi square test obtained $P$ value $<0,000$. Conclusions, there is a relationship between exclusive breastfeeding on infant development and bivariate analysis of maternal education on infant development. There is a relationship between mother's education and infant development.

Keywords: Exclusive ASI, Mother's Education, Infant Development 


\section{PENDAHULUAN}

Setiap bayi berhak mendapatkan Air Susu Ibu (ASI) eksklusif sejak dilahirkan selama 6 bulan kecuali atas indikasi medis (Pasal 128 ayat (1) UU Kesehatan No 36 tahun 2009). Dengan adanya UU Kesehatan nomor 36 tahun 2009 ini, jelas bahwa seorang anak yang baru dilahirkan dalam kondisi normal, artinya tidak memerlukan tindakan penanganan khusus berhak mendapatkan ASI secara eksklusif. Sedangkan kriteria indikasi medis itu dijelaskan bahwa yang dimaksud dengan indikasi medis dalam ketentuan ini adalah kondisi kesehatan ibu yang tidak memungkinkan memberikan ASI berdasarkan indikasi medis yang ditetapkan oleh tenaga medis (Pasal 128 UU Kesehatan nomor 36 tahun 2009).

Dalam penjelasan pasal ini disebutkan bahwa yang dimaksud dengan pemberian ASI eksklusif adalah pemberian hanya air susu ibu selama 6 bulan dan dapat terus dilanjutkan sampai dengan 2 (dua) tahun dengan memberikan Makanan Pendamping Air Susu Ibu (MP-ASI) sebagai tambahan makanan sesuai dengan kebutuhan bayi (UU Kesehatan nomor 36 tahun 2009).

Air Susu Ibu (ASI) merupakan sumber makanan paling sempurna untuk bayi karena memiliki kandungan berbagai zat dan antibodi yang penting untuk pertumbuhan dan perkembangan bayi. Bayi yang menerima ASI eksklusif telah terbukti lebih cerdas dan sulit terserang peyakit. Seiring pertumbuhannya, asupan gizi yang dibutuhkan bayi bertambah dan saluran cerna bayi semakin berkembang maka diperlukan Makanan Pendamping ASI (MP-ASI) agar bayi bisa tumbuh dan berkembang secara maksimal (Sutomo \& Yanti, 2010; Pitaloka et al., 2018).

Menurut WHO, ASI eksklusif didefinisikan sebagai pemberian hanya ASI saja kepada bayi baik dari ibu kandung atau ibu asuh ataupun ASI perah, tanpa ada tambahan berupa cairan atau makanan padat bahkan air putih sekalipun kecuali bagi bayi yang membutuhkan bantuan penambahan cairan, tetesan atau sirup yang berisi vitamin, suplemen mineral atau obat-obatan lainnya (WHO, 2009; Stuebe, 2009; Binns, 2014; Thatrimontrichai, 2012).

Banyak faktor yang berpengaruh untuk menyukseskan ASI eksklusif diantaranya pengetahuan, pendidikan, pekerjaan, sosial budaya, peran tenaga kesehatan, kondisi fisik ibu dan bayi. Banyak alasan bagi ibu tidak memberikan ASI eksklusif diantaranya produksi ASI tidak mencukupi serta rendahnya tingkat pemahaman ibu yang kurang tentang pentingnya ASI eksklusif. Terhentinya ASI eksklusif terjadi pada ibu menyusui karena kurang pengetahuan ibu. Kendala tersebut dapat menghambat pemberian ASI eksklusif sehingga pemberian ASI eksklusif menjadi tidak tercapai secara optimal (Perinasia, 2009).

Tingkat pendidikan ibu dan pengetahuan ibu dapat mendukung keberhasilan ASI eksklusif pada bayi balita. Semakin tinggi tingkat pendidikan seseorang semakin mudah menerima informasi sehingga semakin banyak pengetahuan yang dimiliki. Sebaliknya pendidikan yang kurang akan menghambat perkembangan sikap seseorang terhadap nilai-nilai yang diperkenalkan.

Tumbuh kembang mencakup 2 peristiwa yang sifatnya berbeda, namun saling berkaitan dan sulit dipisahkan, yaitu pertumbuhan dan perkembangan (Ranuh, 2014). Tumbuh kembang fisik maupun mental dan kecerdasan yang ideal pada anak merupakan dambaan setiap orang tua. Maka dari itu sangat diharapkan agar orang tua mengetahui setiap tahapan tumbuh kembang anak. Salah satu perkembangan bayi yang diutamakan adalah perkembangan motorik kasar meliputi gerakan dan penguasaan anggota badan dan kelompok utama semacam menegakkan kepala, miring kanan kiri, 
berguling, merangkak, duduk tanpa bantuan, berdiri, berjalan, melompat memanjat, berlari, menaiki sepeda dan aktivitas lainnya (Indraswari, 2012). Gangguan pertumbuhan dan perkembangan anak di Indonesia mencapai 35,7\% dan tergolong dalam masalah kesehatan yang tinggi menurut acuan WHO karena masih diatas $30 \%$ (Riskesdas, 2013).

Faktor-faktor yang mempengaruhi proses tumbuh kembang salah satunya yaitu memberikan asupan gizi yang cukup terutama saat bayi lahir dipenuhi dengan pemberian ASI secara eksklusif. WHO merekomendasikan anak seharusnya diberikan ASI eksklusif sampai usia enam bulan tanpa cairan atau makanan padat apapun (Lissauer, 2009; Wieland \& Santesso, 2016).

Salah satu upaya meningkatkan perkembangan bayi adalah dengan pemberian ASI eksklusif. Air Susu Ibu merupakan faktor lingkungan dan kebutuhan asuh yang mengandung nutrisi terbaik bagi bayi karena ASI mengandung semua zat gizi dengan jumlah dan komposisi yang ideal serta sifat ASI yang sangat mudah diserap oleh tubuh bayi sangat bermanfaat untuk membantu pertumbuhan dan perkembangan bayi yang optimal serta melindungi terhadap berbagai penyakit (Soetijaningsih, 2013; Oktiyani et al., 2015).

Menurut Peraturan Pemerintah nomor 33 tahun 2012 dan Undang - Undang Kesehatan nomor 36 tahun 2009 Pasal 128 dan Pasal 129 menjelaskan bahwa pemberian ASI eksklusif adalah menyusui bayi segera setelah lahir, hanya ASI saja tanpa makanan dan minuman lain sampai bayi berumur 6 bulan (Peraturan Presiden RI, 2009).

ASI memiliki kandungan yang berguna untuk proses myelinisasi atau pembentukan selaput di saraf otak yang dapat mempercepat kerja saraf yaitu AA dan DHA. Jika proses myelinisasi berhasil, maka sinyal dari saraf bayi yang berkerja dengan baik dikirim ke tubuh yang dikendalikan oleh otak akan bekerja secara baik juga. AA dan DHA pada ASI berbeda dengan yang ada di susu formula yang mana AA dan DHA pada ASI jauh lebih mudah diserap usus bayi (Khamzah, 2012). Selain itu, ASI mengandung taurin yaitu sejenis asam amino yang hanya ada ditemukan di ASI. Taurin berfungsi sebagai neurotransmitter dan berperan penting untuk proses maturasi sel otak. Kemampuan perkembangan mental dan motorik khususnya motorik kasar anak berkorelasi dengan konsentrasi taurin pada masa bayi.

Belfield et al., (2010) dalam penelitiannya menjelaskan bahwa menyusui dapat meningkatkan probabilitas anak menjadi lebih sehat dan dapat mencegah terjadinya obesitas. Selain itu, menyusui selama 6 bulan atau lebih dapat meningkatkan perkembangan motorik kasar pada saat anak berusia 9 bulan.

Perkembangan motorik kasar merupakan bagian tak terpisahkan dari perkembangan anak secara keseluruhan. Perkembangan motorik kasar merupakan aspek yang berhubungan dengan pergerakan dan sikap tubuh, di sektor ini akan dinilai kemampuan anak dalam penggunaan otot-otot penunjang gerak tubuh seperti melempar, melangkah, melompat, berdiri, dan lain sebagainya (Padila et al., 2019).

Lebih lanjut menurut Padila et al., (2019) di usia bayi 0-12 bulan perkembangan motorik kasar merupakan faktor pekembangan yang pertama kali dapat dilihat oleh orangtua, seperti anak mengangkat kaki nya, menggerakan tangan nya, menggerakkan kepala kekanan dan kekiri, belajar terlungkup dan terlentang, mengangkat kepala setinggi $90^{\circ}$, meraih benda di jangkauannya dan kemampuan gerak motorik kasar lainnya. 


\section{METODE PENELITIAN}

Penelitian ini bersifat kuantitatif analitik observasional dengan desain cross sectional dengan besar sampel 83 orang. Metode sampling yang digunakan yaitu proportional sampling. Pengumpulan data dengan cara menyebarkan kuesioner kepada responden, sumber data diperoleh dari data primer. Analisis data dilakukan secara univariat dan bivariat. Analisis data univariat meliputi distribusi frekuensi sedangkan bivariat dengan menggunakan uji chi square.

\section{HASIL PENELITIAN Analisa Univariat}

Tabel. 1

Distribusi variabel Independen dan Dependen tentang Hubungan Pemberian Asi Eksklusif dan Pendidikan Ibu terhadap Perkembangan Bayi

\begin{tabular}{lcc}
\hline \multicolumn{1}{c}{ Variabel } & $\begin{array}{c}\text { Jumlah } \\
(\mathrm{n}=83)\end{array}$ & $\begin{array}{c}\text { Jumlah } \\
(100 \%)\end{array}$ \\
\hline ASI Eksklusif & 37 & 44,6 \\
$\quad$ Tidak & 36 & 55,4 \\
$\quad$ Ya & & \\
\hline Pendidikan Ibu & 56 & 67,5 \\
$\quad$ Rendah & 27 & 32,5 \\
$\quad$ Tinggi & & \\
Perkembangan Bayi & 36 & 43,4 \\
$\quad$ Terlambat & 47 & 56,6 \\
$\quad$ Normal & &
\end{tabular}

Berdasarkan tabel 1 menunjukkan bahwa dari 83 responden terdapat sebanyak 55,4 persen ibu yang memberikan ASI Eksklusif kepada bayinya, pendidikan ibu mayoritas rendah sebanyak 67,5 persen dan mayoritas perkembangan bayi normal sebanyak 56,6 persen.

\section{Analisa Bivariat}

Tabel. 2

Hubungan Pemberian ASI Eksklusif terhadap

Perkembangan Bayi

\begin{tabular}{cccccccc}
\hline Kategori & $\mathrm{n}$ & $(\%)$ & $\mathrm{n}$ & $(\%)$ & Jumlah P Value & OR \\
\hline ASI Eksklusif & & & & & & 5,23 \\
Tidak & 24 & $(64,9)$ & 13 & $(35,1)$ & $(100)$ & $<0,000$ & $(2,038-$ \\
Ya & 12 & $(26,1)$ & 34 & $(73,9)$ & $(100)$ & & $13,427)$ \\
\hline
\end{tabular}

Berdasarkan tabel 2 menunjukkan, dari hasil penelitian dapat dilihat bahwa ibu yang memberikan ASI eksklusif mempunyai perkembangan yang normal sebanyak 73,9 persen, sedangkan ibu yang tidak memberikan ASI eksklusif mempunyai perkembangan bayi yang normal sebanyak 35,1 persen. Dari hasil uji chi-square diperoleh hasil $P$ value $<0,000$ artinya ada hubungan antara pemberian ASI eksklusif terhadap perkembangan bayi. Dengan nilai OR 5,23 yang artinya ibu yang tidak memberikan ASI eksklusif lebih berisiko 5,23 kali mempunyai perkembangan bayi yang terhambat dibandingkan dengan ibu yang memberikan ASI Eksklusif. 
Tabel. 3

Hubungan Pendidikan Ibu terhadap Perkembangan Bayi

\begin{tabular}{lcccccccc}
\hline $\begin{array}{c}\text { Variabel } \\
\text { Independen dan } \\
\text { Kategori }\end{array}$ & \multicolumn{2}{c}{$\begin{array}{c}\text { Perkembangan Bayi } \\
\text { Terlamt } \\
(\%)\end{array}$} & $\mathrm{n}$ & $\begin{array}{c}\text { Normal } \\
(\%)\end{array}$ & $\mathrm{n}$ & $(\%)$ & Pumlah & OR (95\% \\
\hline $\begin{array}{l}\text { Pendidikan Ibu } \\
\text { Rendah }\end{array}$ & 30 & $(52,6)$ & 27 & $(47,4)$ & 57 & $(100)$ & 0,012 & CI) \\
Tinggi & 6 & $(23,1)$ & 20 & $(76,9)$ & 26 & $(100)$ & & $\begin{array}{c}3,7 \\
1,296- \\
10,585)\end{array}$ \\
\hline
\end{tabular}

Berdasarkan tabel 3 menunjukkan hasil penelitian bahwa ibu yang berpendidikan tinggi mempunyai perkembangan bayi normal sebanyak 76,9 persen, sedangkan ibu yang berpendidikan rendah mempunyai perkembangan bayi yang normal sebanyak 47,4 persen. Dari hasil uji chi-square diperoleh hasil Pvalue 0,012 artinya ada hubungan antara pendidikan ibu terhadap perkembangan bayi dengan nilai OR 3,7 yang artinya ibu yang berpendidikan rendah lebih berisiko 3,7 kali mempunyai perkembangan bayi yang terhambat dibandingkan dengan ibu yang berpendidikan tinggi.

\section{PEMBAHASAN}

Berdasarkan hasil penelitian diatas bahwa ibu yang memberikan ASI eksklusif mempunyai perkembangan bayi yang normal sebanyak 73,9 persen, sedangkan ibu yang tidak memberikan ASI eksklusif mempunyai perkembangan bayi yang normal sebanyak 35,1 persen. Dari hasil uji chi-square diperoleh hasil $p$ value $<0,000$ artinya ada hubungan antara pemberian ASI eksklusif terhadap perkembangan bayi. Dengan nilai OR 5,23 yang artinya ibu yang tidak memberikan ASI eksklusif lebih berisiko 5,23 kali mempunyai perkembangan bayi yang terhambat dibandingkan dengan ibu yang memberikan ASI eksklusif.

Hasil penelitian ini didukung oleh hasil penelitian Ali et al., (2014) bahwa anakanak yang mendapatkan ASI eksklusif selama 6 bulan atau lebih memiliki skor ASQ (Ages and Stages Questionnaire) lebih tinggi dengan nilai $\mathrm{p}(0,004)$ pada sektor motorik kasar dibandingkan dengan anak-anak yang tidak mendapatkan ASI eksklusif dengan nilai $\mathrm{p}(0,091)$. Sehingga dapat disimpulkan bahwa ASI eksklusif memiliki peran dalam tumbuh kembang anak, khususnya pada sektor motorik kasar (Ali et al., 2014).

Hasil penelitian ini tidak sejalan dengan penelitian yang dilakukan oleh Fitri et al., (2014) yang menyatakan bahwa tidak ada hubungan antara pemberian ASI eksklusif dengan pertumbuhan dan perkembangan anak. Hasil penelitian ini sebanding dengan penelitian yang dilakukan oleh Budi Cahyadi di kelurahan Linggajaya kecamatan Mangkubumi kota Tasikmalaya tahun 2012 bahwa hubungan pemberian ASI tidak signifikan dengan pertumbuhan bayi (Cahyadi, 2012).

Bayi yang mendapatkan ASI eksklusif umumnya akan mengalami pertumbuhan yang pesat pada umur 2-3 bulan, namun lebih lambat dibandingkan bayi yang mendapat ASI non eksklusif. Hasil penelitian retrospektif di Baltimore-Washington DC bahwa dalam kondisi yang optimal, ASI eksklusif mendukung pertumbuhan bayi selama 6 bulan pertama sehingga status gizi mencapai normal (Tikoalu, 2008).

Hubungan pemberian ASI tidak signifikan dengan pertumbuhan bayi kemungkinan disebabkan oleh kuantitas dan kualitas ASI yang diberikan ibu yang masih kurang dan belum memenuhi kebutuhan bayi sehingga penembahan berat badan dan panjang badan bayi menjadi tidak optimal. Selain itu faktor gizi pada ibu saat hamil 
dan menyusui, cara menyusui yang belum tepat dan benar sehingga produksi ASI tidak sempurna (Fitri et al., 2014).

Hasil penelitian Febriana (2015) tentang Hubungan Pemberian ASI eksklusif dengan perkembangan bayi usia 9-12 bulan di Puskesmas Gamping I Sleman diperoleh hasil bahwa responden ASI eksklusif dengan perkembangan bayi normal sebanyak 24 bayi (80\%), perkembangan bayi suspect sebanyak 0 bayi (0\%), dan perkembangan bayi untestable sebanyak 1 bayi (3,3\%). Sedangkan untuk responden yang tidak memberikan ASI eksklusif dengan perkembangan bayi normal sebanyak 2 bayi (6,7\%), perkembangan bayi suspect sebanyak 2 bayi $(6,7 \%)$, dan perkembangan bayi untestable 1 bayi (3,3\%) (Febriana, 2015).

Perkembangan di masa bayi merupakan bagian penting dan tak terpisahkan untuk menentukan perkembangan anak selanjutnya dikemudian hari. Penting bagi orangtua mengetahui aspek perkembangan bayi dan menstimulus dengan baik setiap aspek perkembangan yang ada. Karena apabila anak berada pada aspek perkembangan yang meragukan (suspect) maka ibu perlu ditekankan untuk melakukan stimulasi lebih sering sesuai usia perkembangan anak setiap saat dan sesering mungkin (Padila et al., 2019).

Faktor terpenting dalam proses pertumbuhan termasuk pertumbuhan otak adalah nutrisi yang diberikan. Faktor- faktor yang mempengaruhi kuantitas dan kualiatas nutrisi secara langsung juga dapat mempengaruhi pertumbuhan otak. Memberikan ASI secara eksklusif sampai bayi berusia 6 bulan akan menjamin tercapainya pengembangan potensi kecerdasan anak secara optimal (Roesli,2009).

Otak bayi memiliki sisi positif dan negatif. Sisi positif dari otak pada bayi yaitu lebih peka untuk proses pembelajaran dan pengkajian dan sisi negatif dari otak pada bayi yaitu lebih sensitif atau peka terhadap lingkungan yang tidak mendukung seperti asupan gizi atau nutrisi yang tidak seimbang, kurangnya stimulasi dan pelayanan kesehatan yang kurang laik. Masa pada lima tahun pertama kehidupan pada anak merupakan masa yang sangat sensitif atau peka terhadap lingkungan dan masa ini berlangsung sangat pendek serta tidak dapat diulang lagi, atau disebut dengan masa keemasan (golden period), jendela kesempatan (window of opportunity) dan masa kritis (critical period) (Depkes, 2006 dalam Lisa, 2012).

Menurut Notoatmojdo (2007) menjelaskan tentang konsep pendidikan yang merupakan suatu proses yang berarti di dalam pendidikan itu terjadi proses pendidikan, perkembangan atau perubahan ke arah yang lebih dewasa, lebih baik dan lebih matang pada diri individu, kelompok dan masyarakat. Semakin tinggi tingkat pendidikan maka ia akan mudah menerima hal-hal baru dan mudah menyesuaikan hal- hal baru tersebut. Ibu yang berpendidikan tinggi mempunyai perkembangan bayi normal sebanyak 76,9 persen, sedangkan ibu yang berpendidikan rendah mempunyai perkembangan bayi yang normal sebanyak 47,4 persen. Dari hasil uji chi-square diperoleh hasil $P$ value 0,012 artinya ada hubungan antara pendidikan ibu terhadap perkembangan bayi dengan nilai OR 3,7 yang artinya ibu yang berpendidikan rendah lebih berisiko 3,7 kali mempunyai perkembangan bayi yang terhambat dibandingkan dengan ibu yang berpendidikan tinggi.

Penelitian yang dilakukan oleh Lestari (2018) menyatakan bahwa tingkat pendidikan mempengaruhi pemberian asi eksklusif yang nantinya akan berpengaruh pada pertumbuhan dan perkembangan anak.

Pendidikan diperkirakan ada kaitannya dengan ibu menyusui dalam memberikan ASI ekslusif, hal ini juga dihubungkan dengan tingkat pengetahuan ibu bahwa seseorang yang berpendidikan lebih tinggi akan mempunyai pengetahuan yang lebih 
luas dibandingkan tingkat pendidikan yang rendah (Notoatmodjo, 2007).

Penelitian ini sejalan dengan penelitian Sriningsih (2010) didapat kesimpulan bahwa ada hubungan bermakna antara tingkat pendidikan dengan pemberian ASI ekslusif dengan nilai $p$ value $(0,003)<\alpha(0,05)$, dimana ibu yang memiliki pendidikan tinggi lebih banyak memberikan ASI ekslusif dibandingkan ibu yang berpendidikan rendah.

Penelitian Lisa tahun 2012 tentang hubungan pemberian ASI eksklusif dengan perkembangan motorik kasar balita menyatakan bahwa ada hubungan bermakna antara pemberian ASI eksklusif dengan perkembangan motorik kasar. Asupan gizi yang tidak adekuat dan stimulasi yang kurang dapat mempengaruhi perkembangan otak anak. Upaya dalam membentuk perkembangan yang optimal sedini mungkin sangatlah tergantung pada pemberian ASI. Ibu yang memberikan ASI termasuk kolostrum, bukan saja memberikan nutrisi bagi bayi, tetapi juga kasih sayang yang berfungsi sebagai stimulasi psikososial. Pemberian ASI sedini mungkin segera setelah bayi lahir, merupakan stimulasi dini terhadap tumbuh kembang anak.

Menurut penelitian Ransum et al., (2013) hasil penelitian menunjukan bahwa sekitar 44,5\% responden yang memberikan ASI secara eksklusif dan 55,4 \% non eksklusif. Ada hubungan pendidikan ibu dengan pemberian ASI eksklusif (Ullya, 2013). Begitu juga dengan hasil penelitian yang dilakukan oleh Hartini diketahui bahwa dari 20 responden yang berpendidikan rendah, 10 responden $(50 \%)$ diantaranya tidak berhasil memberikan ASI eksklusif kepada bayinya. Sementara itu, responden yang berpendidikan menengah mempunyai prevalensi keberhasilan ASI eksklusif sebesar $95,2 \%$, dan yang berpendidikan tinggi sebesar 85,2\% (Hartini, 2014).

Sesuai yang diungkapkan oleh Manuaba (2001) tingkat pendidikan ibu berpengaruh dalam praktek menyusui. Semakin tinggi tingkat pendidikan ibu, maka pengetahuan ibu semakin baik. Hal ini akan memberikan kecenderungan ibu dalam bersikap dengan memberikan yang terbaik bagi bayi. Pendidikan seorang ibu yang rendah memungkinkan ia lambat dalam mengadopsi pengetahuan baru, khususnya tentang hal-hal yang berhubungan dengan pola pemberian ASI.

Dalam sepuluh langkah menuju keberhasilan menyusui, petugas kesehatan mempunyai peranan untuk memberikan informasi kepada ibu hamil tentang manfaat menyusui dan pelaksanaannya, sehingga ibu hamil mempunyai pengetahuan tentang ASI ekslusif. Untuk memberikan informasi, petugas perlu diberi pelatihan dalam hal pengetahuan dan keterampilan untuk menerapkan kebijakan peningkatan pemberian ASI (Lestari, 2018).

Kandungan Air Susu Ibu (ASI) mempunyai kandungan yang baik untuk perkembangan bayi antara lain taurin merupakan suatu bentuk zat putih telur yang hanya terdapat pada ASI berguna untuk neotransmitter yang berperan penting pada proses perkembangan otak dan retina, laktosa yaitu karbohidrat utama dalam ASI yang berfungsi sebagai sumber energi untuk kebutuhan tumbuh kembang bayi dan. Lemak di ASI mengandung komponen asam lemak esensial yaitu asam linoleat dan asam alda linolenat yang akan diolah tubuh bayi menjadi AA dan DHA. ASI terdapat kadar lemak yang lebih tinggi dibandingkan susu formula (6:1). Kadar lemak yang tinggi dibutuhkan untuk mendukung perkembangan otak yang cepat semasa bayi. Arachidonic Acid (AA) dan Decosahexanoic Acid (DHA) adalah asam lemak tak jenuh rantai panjang (longchain polyunsaturated fatty acid) yang bukan hanya berfungsi untuk sumber energi, tetapi juga sangat penting bagi perkembangan sel - sel otak yang dapat mempengaruhi fungsi mental, penglihatan dan perkembangan psikomotorik bayi (Hidayati, 2012; 
Maryunani, 2012; Intani et al., 2019).

Kandungan ASI sangat bermanfaat sebagai nutrisi makanan terlengkap yang merupakan kebutuhan asuh untuk bayi, pemberian ASI juga memberikan kekebalan tubuh, meningkatkan jalinan kasih sayang, dapat menunjang perkembangan motorik, menunjang perkembangan kepribadian, kecerdasan emosional, kematangan spiritual dan hubungan sosial yang baik. Hal ini dikarenakan pada saat menyusui, antara ibu dan bayi terjadi kontak fisik dan psikis sedini mungkin dengan ibunya, kebutuhan anak akan kasih sayang, diperhatikan dan dihargai memberikan rasa aman pada bayinya dan terjadi proses stimulasi yang merangsang terbentuknya kerjasama antar jaringan otak hingga menjadi lebih banyak dan terjalin sempurna sehingga dapat merangsang kemampuan dasar perkembangan bayi sejak dini, Ini terjadi melalui suara, tatapan mata, denyut jantung, elusan, pancaran dan rasa ASI (Maryunani, 2012; Khamzah, 2012).

\section{SIMPULAN}

Berdasarkan hasil penelitian dapat disimpulkan ada hubungan antara pemberian ASI eksklusif terhadap perkembangan bayi dengan nilai OR 5,23 yang artinya ibu yang tidak memberikan ASI eksklusif lebih berisiko 5,23 kali mempunyai perkembangan bayi yang terhambat dibandingkan dengan ibu yang memberikan ASI eksklusif. Ada hubungan antara pendidikan ibu terhadap perkembangan bayi dengan nilai OR 3,7 yang artinya ibu yang berpendidikan rendah lebih berisiko 3,7 kali mempunyai perkembangan bayi yang terhambat dibandingkan dengan ibu yang berpendidikan tinggi.

\section{SARAN}

Bagi ibu terus memberikan pola asuh yang baik serta lebih memperhatikan asupan ASI eksklusif bayi diawal kehidupannya bagi bayi khususnya pada usia 0-6 bulan, karena ASI dapat meningkatkan perkembangan bayi terutama motorik kasarnya

\section{DAFTAR PUSTAKA}

Ali, S. S., Sangappa, D. M., \& Goudar, S. S. (2014). The Impact of Nutrition on Child Development at 3 Years in a Rural Community of India. International journal of preventive medicine 5(4), 494-9

Belfield, C. R., \& Kelly, I. R. (2010). The Benefits Of Breastfeeding Across The Early Years Of Childhood. NBER Working Paper

Binns, C. W, Lee, M. K. (2014). Exclusive Breastfeeding for Six Months: the WHO Six Months Recommendation in the Asia Pacific Region. Asian Pac J Clin Nutr, 23(3), 334-50

Cahyadi, B. (2012). Hubungan Pemberian ASI Eksklusif dengan Status Gizi Bayi Usia 6-8 Bulan di Wilayah Kelurahan Linggajaya Kecamatan Mangkubumi Kota Tasikmalaya 2012. [serial online] 2012. (diunduh 13 September 2013). Tersedia dari: URL: Hyperlink http://journal.unsil.ac.id/jurnalunsil-753-.html

Febriana, F. (2015). Hubungan Pemberian Asi Eksklusif dengan Perkembangan Bayi Usia 9-12 Bulan di Puskesmas Gamping I Sleman. Yogyakarta: STIKES Aisyiyah Yogyakarta

Fitri, D. I., Chundrayetti, E., \& Semiarty, R. (2014). Hubungan Pemberian ASI dengan Tumbuh Kembang Bayi Umur 6 Bulan di Puskesmas Nanggalo. Jurnal Kesehatan Andalas, 3(2), 136-140. http://jurnal.fk.unand.ac.id

Hartini, S. (2014). Hubungan Tingkat Pendidikan Ibu dengan Keberhasilan ASI Eksklusif pada Bayi Umur 6-12 Bulan di Puskesmas Kasihan II Yogyakarta. 
Yogyakarta: STIKES Aisyiyah Yogyakarta

Hidayati, A. (2012). Mengapa Seorang Ibu Harus Menyusui. Yogyakarta: Flashbook; 2012.hlm.190-1

Indraswari, L. (2012). Peningkatan Perkembangan Motorik Halus Anak Usia Dini Melalaui Kegiatan Mozaik di Taman Kanak-Kanak Pembina Agam. Jurnal Pesona PAUD, 1(1), 1-13

Intani, T. M., Syafrita, Y., \& Chundrayetti, E. (2019). Hubungan Pemberian ASI Eksklusif dan Stimulasi Psikososial dengan Perkembangan Bayi Berumur 6-12 Bulan. Jurnal Kesehatan Andalas, 8(1), 7-13. http://jurnal.fk.unand.ac.id

Khamzah, S. N. (2012). Segudang Keajaiban ASI yang Harus Anda Ketahui. Yogyakarta: Flashbooks, 160-2

Lestari, R. R. (2018). Faktor-Faktor yang Berhubungan dengan Pemberian ASI Eksklusif pada Ibu. Jurnal Obsesi: Jurnal Pendidikan Anak Usia Dini, 2(1), 131136. http://obsesi.or.id/index.php/obsesi

Lisa, U. F. (2012). Hubungan Pemberian Asi Eksklusif dengan Perkembangan Motorik Kasar Balita di Kelurahan Brontokusuman Kecamatan Mergangsan Yogyakarta. Jurnal Ilmiah STIKES U'Budiyah, 1(2), 34-37. http://ejournal.uui.ac.id/jurnal/Ulfa_Farrah_Lisa-uha-5-ulfa_farrah_lisa.pdf

Lissauer, T. F. (2009). At a Glance Neonatalagi. Jakarta: Erlangga Medical Series

Manuaba, M. (2001). Ilmu Kebidanan, Penyakit Kandungan dan Keluarga Berencana untuk Pendidikan Bidan. Jakarta: EGC

Maryunani, A. (2012). Inisiasi Menyusu Dini ASI Eksklusif dan Manajemen Laktasi. Jakarta: TIM, 45- 54

Notoatmodjo, S. (2007). Promosi Kesehatan dan Perilaku Kesehatan. Jakarta: Rineka Cipta

Oktiyani, P., Nugraheni, S. A., \& Rahfiludin, Z. (2015). Hubungan Pemberian ASI Eksklusif dengan Perkembangan Bayi Usia $0-6$ Bulan di Wilayah Kerja Puskesmas Padangsari Kota Semarang. Jurnal Kesehatan Masyarakat. 3(1), 2717

Padila, P., Andari, F. N., Harsismanto, J., \& Andri, J. (2019). Tumbuh Kembang Anak Usia Toddler Berbasis Research. Lubuklinggau: Asra

Peraturan Pemerintah no 33. 2013 tentang Pemberian Air Susu Eksklusif. Jakarta: Pemerintah RI; 2013.hlm;6-7

Peraturan Presiden RI. Undang-Undang Republik Indonesia no 36 tahun 2009 tentang Kesehatan Pasal 128 dan Pasal 129. Jakarta: Peraturan Presiden Republik Indonesia ; 2009.hlm.30

Perinasia, P. (2009). Bahan Bacaan Manajemen Laktasi Cetakan ke 2. Jakarta: Perinasia

Pitaloka, D. A., Abrory, R., \& Pramita, A. D. (2018). Hubungan antara Pengetahuan dan Pendidikan Ibu dengan Pemberian ASI Eksklusif di Desa Kedungrejo Kecamatan Waru Kabupaten Sidoarjo. Open access under CC BY - SA license. DOI : 10.2473/amnt.v2i3.2018.265-270

Ransum, U. P., Syam, A., \& Hendrayati, H. (2013). Hubungan Sikap Ibu, Pendidikan dan Dukungan Petugas Kesehatan dengan Pemberian ASI Eksklusif pada Bayi Umur 6 -11 Bulan di Puskesmas Antang Perumnas Kota Makassar. Jurnal Medical Ners, 2(1)

Ranuh, S. (2014). Tumbuh Kembang Anak Edisi 2. Jakarta: Buku Kedokteran EGC

Riskesdas. (2013). Riset Kesehatan Dasar (Riskesdas) 2013. Laporan Nasional 2013, 
1-384. https://doi.org/

Roesli, U. (2009). ASI Panduan Praktis Ibu Menyusui. Yogyakarta: Banyu Media

Soetijaningsih, R. I. G. (2013). Tumbuh dan kembang Edisi Ke-2. Jakarta: EGC. hlm.14-47

Sriningsih, I. (2010). Faktor Demografi, Pengetahuan Ibu tentang ASI dan Pemberian ASI Ekslusif. Jurnal Kesehatan Masyarakat, 6(2), 100-106

Stuebe, A. (2009). The Risks of not Breastfeeding for Mothers and Infants. Rev Obstet Gynecol, 2(4), 222-31

Sutomo, B., \& Yanti, D. (2010). Sajian Lezat Makanan Sehat Pendamping ASI. (Demedia, 2010)

Thatrimontrichai, A., Janjindamai, W., \& Puwanant, M. (2012). Fat Loss in Thawed Breast Milk: Comparison between Refrigerator and Warm Water. Indian Pediatr, 49, 877-80

Tikoalu,, Jeanne, R., \& Sekartin, R. (2008). Air Susu Ibu dan Tumbuh Kembang Anak Dalam Bedah ASI. Jakarta: Balai Penerbit FKUI

Undang-undang RI No. 36 Tahun 2009 tentang Kesehatan. (2009). Jakarta

WHO. (2009). Infant and Young Child Feeding: Model Chapter for Textbooks for Medical Students and Allied Health Professionals, 1-112

Wieland, L. S., \& Santesso, N. (2016). A Summary of a Cochrane Review: Supplementation with Long Chain Polyunsaturated Fatty Acids (LCPUFA) to Breastfeeding Mothers for Improving Child Growth and Development, European Journal of Integrative Medicine, 8(2), 113-114. doi: 10.1016/j.eujim.2016.03.006 